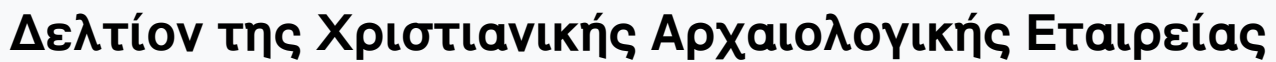

Tóp. 8 (1976)

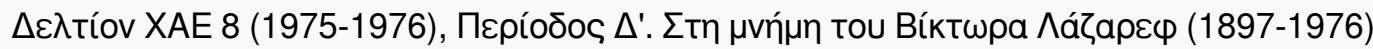

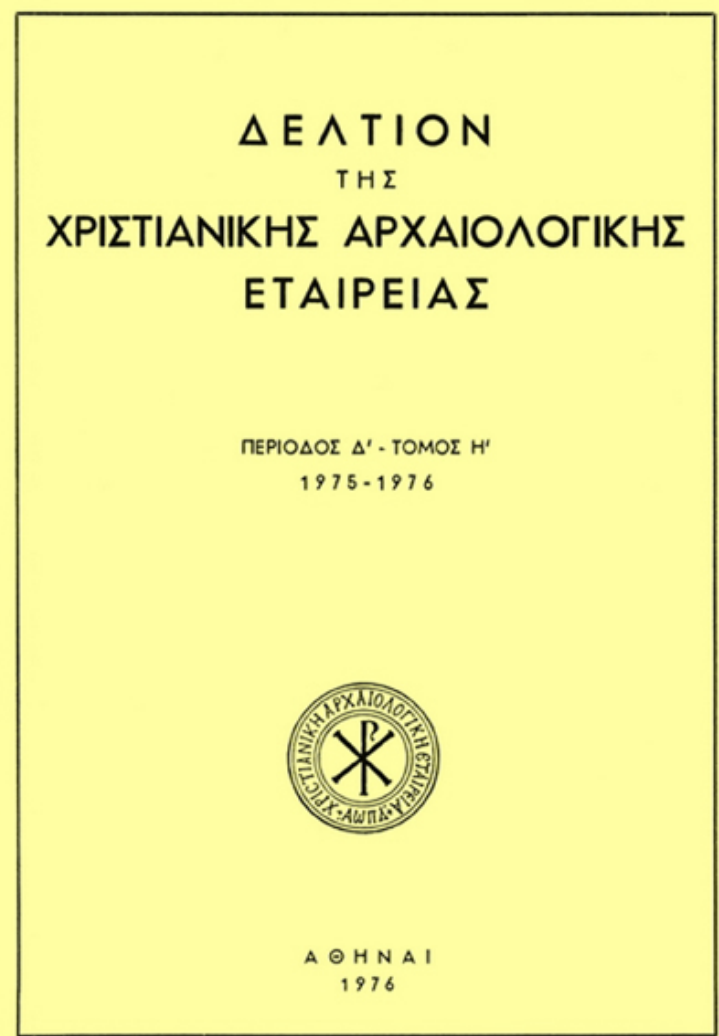

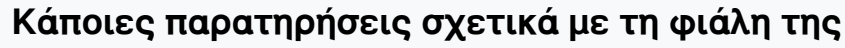

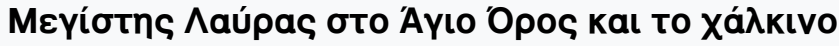

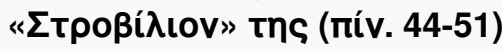

Laskarina BOURAS

doi: $10.12681 /$ dchae.850

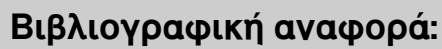

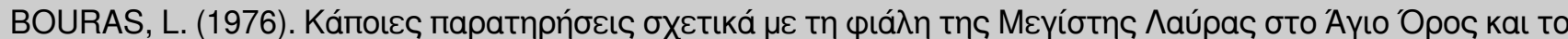

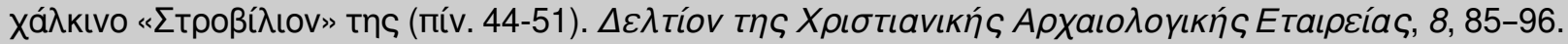
https://doi.org/10.12681/dchae.850 


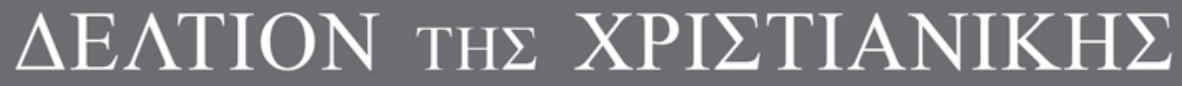 APXAIO $\Lambda$ OГIKH $\Sigma$ ETAIPEIA $\Sigma$}

Some Observations on the Grand Lavra Phiale at Mount Athos and its Bronze Strobilion ( $\pi$ ív. 44-51)

Laskarina BOURAS

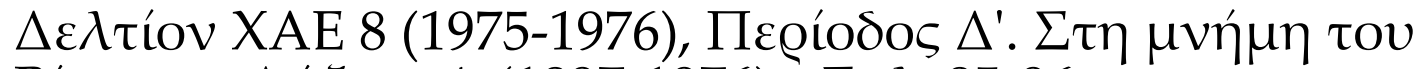

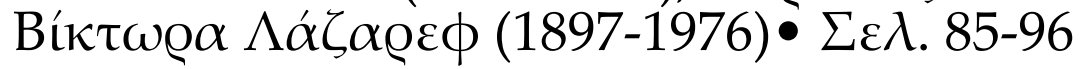

A@HNA 1976 


\section{SOME OBSERVATIONS ON THE GRAND LAVRA PHIALE AT MOUNT ATHOS AND ITS BRONZE STROBILION*}

(PL, $44-51$ )

The presence of the phiale in the atrium of early Christian basilicas indicates the survival of the primeval cult of the waters which was carried over into religious as well as secular architecture of the middle Byzantine period 1 . The term derives from the drinking bowl of the same name and is also used for the structure which is often built over the phiale ${ }^{2}$. Such structures are usually octagonal after the early Christian baptisteries, which adopted the form of Roman mausoleum ${ }^{3}$. Millet pointed out that while the phiale originally served for the ablutions of those entering the church, it is associated from the sixth century onwards with the benediction of waters performed every year during the feast of the Epiphany ${ }^{4}$.

The Byzantine sources are rich in descriptions of medieval phialae decorating crossroads and gardens ${ }^{5}$ or churches of the imperial city and parts of the Great Palace ${ }^{6}$. Such phialae were also exported to Spain for

* I am grateful to the National Research Institute of Greece for the grant which enabled me to undertake this study and to professor D. Mouriki for constant advice and help. I should also like to thank professor P. Vocotopoulos for the picture of pl. $51 \mathrm{a}$, G. Velenis for the pictures of pls. $47_{\mathrm{b}}$ and $48 \mathrm{~b}$ and D. Hardy for the improvement of the English text.

1. H. Le clercq, in D.A.C.L. $V_{2}$, Paris 1923, col. 1859.

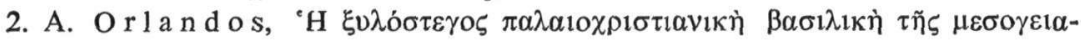

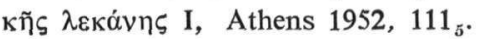

3. P. Underwood, The Fountain of Life in Manuscripts of the Gospels, DOP 5 (1950), 43.

4. G. M i 11 e t, Recherches au Mont-Athos III, BCH 29 (1905), 109.

5. Euse bi u s III, Vita Constantini, ed. Heikel, Leipzig 1902, $49: \ldots \varepsilon i \delta \varepsilon \varsigma$

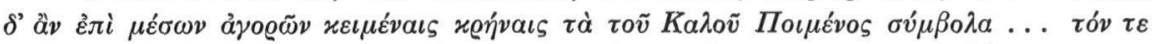

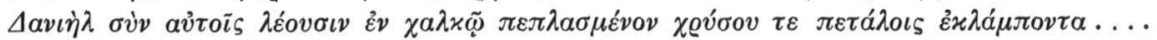
A lavishly decorated garden phiale is described by $\mathrm{Eu} \mathrm{stathios} \mathbf{M a k ~ r e ~ m b o - ~}$

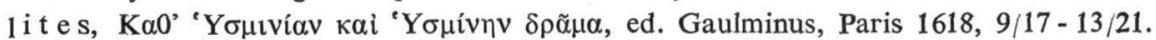

6. Du C a n ge, Glossarium ad Scriptores Mediae et Infimae Graecitatis, Vratislaviae 1891, col. 1675 , 
the Ummayyad Caliphs of Cordova ?. Some of the descriptions refer to gold or silver gilded water spout systems ${ }^{8}$, which were often decorated with various zodia, acting as water spouts. The bronze strobilion of the Grand Lavra phiale at Mout Athos, however, seems to represent the only known example surviving so far.

The Grand Lavra phiale and its strobilion were first noticed by the Russian monk Barskij, who visited the monastery in 1744 and made on that occasion a detailed drawing of the phiale (A) ${ }^{9}$. More than a century later, Didron published a brief description of the bronze conduit ${ }^{10}$. Millet who also devoted an extensive study to the phiale, identified it with the one erected in $1060^{11}$, according to a dedicatory inscription found in the monastery. With reference to the opinion of Barskij that the strobilion was a Venetian work, Millet suggested that in all probability it was only restored by Venetian craftsmen ${ }^{12}$. He also pointed out the trough's striking resemblance to that of the second phiale of the Nea, described in the Vita Basilii and to a description in verse of another phiale in the Asomatos of Lavra(?) by Manuel Philes ${ }^{13}$. Millet, nevertheless, refrained from further comments on the trough as a work of art, his aim being a survey of the liturgical function of the phiale according to the sources.

Located on the west side of the catholikon of the Grand Lavra, the fountain is covered by an octastyle canopy (p1.45) ${ }^{14}$. The dome is decorated

7. Fr. B a r gebuh r, The Alambra Palace of the Eleventh Century, J.W.C.I. XIX (1956), 233. An interesting bronze conduit survives in the Alcazar of Seville, see E. S o rd o, Moorish Spain, London 1963, 86, fig. 34.

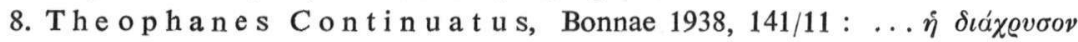

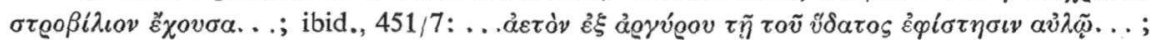

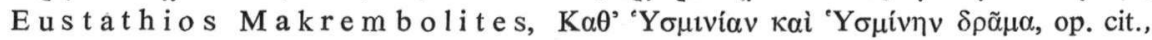

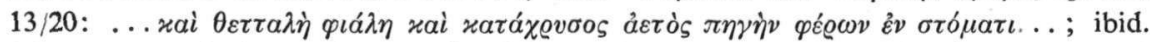
9/20: ...

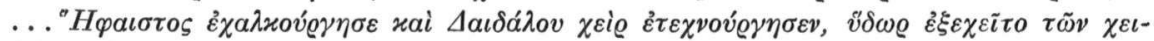

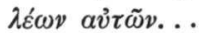

9. B. B a r skij, Vtoroe posescenie svjatoj Afonskoj gory Vasilija GrigorovicaBarskago im samim opisannoe, St. Petersburg 1887, opposite p. 132.

10. D i dro n, Le couvent de St. Laure au Mont Athos, Annales Archéologiques 21 (1861), 80 .

11. G. Millet, J. Pargoire, L. Petit, Recueil des inscriptions chrétiennes de l'Athos, Paris 1904, 107.

12. G. M i 11 e t, Recherches au Mont-Athos, op. cit., 108.

13. Ibid., 108.

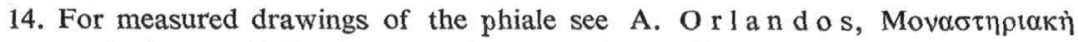

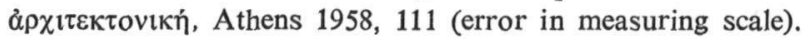


with frescoes depicting scenes related to water ( $\mathrm{pl}$. 46), from the Old and the New Testaments, in accordance with the iconographic program of a phiale, as given in the Hermeneia of Dionysius of Fourna ${ }^{15}$. A long inscription attrib-

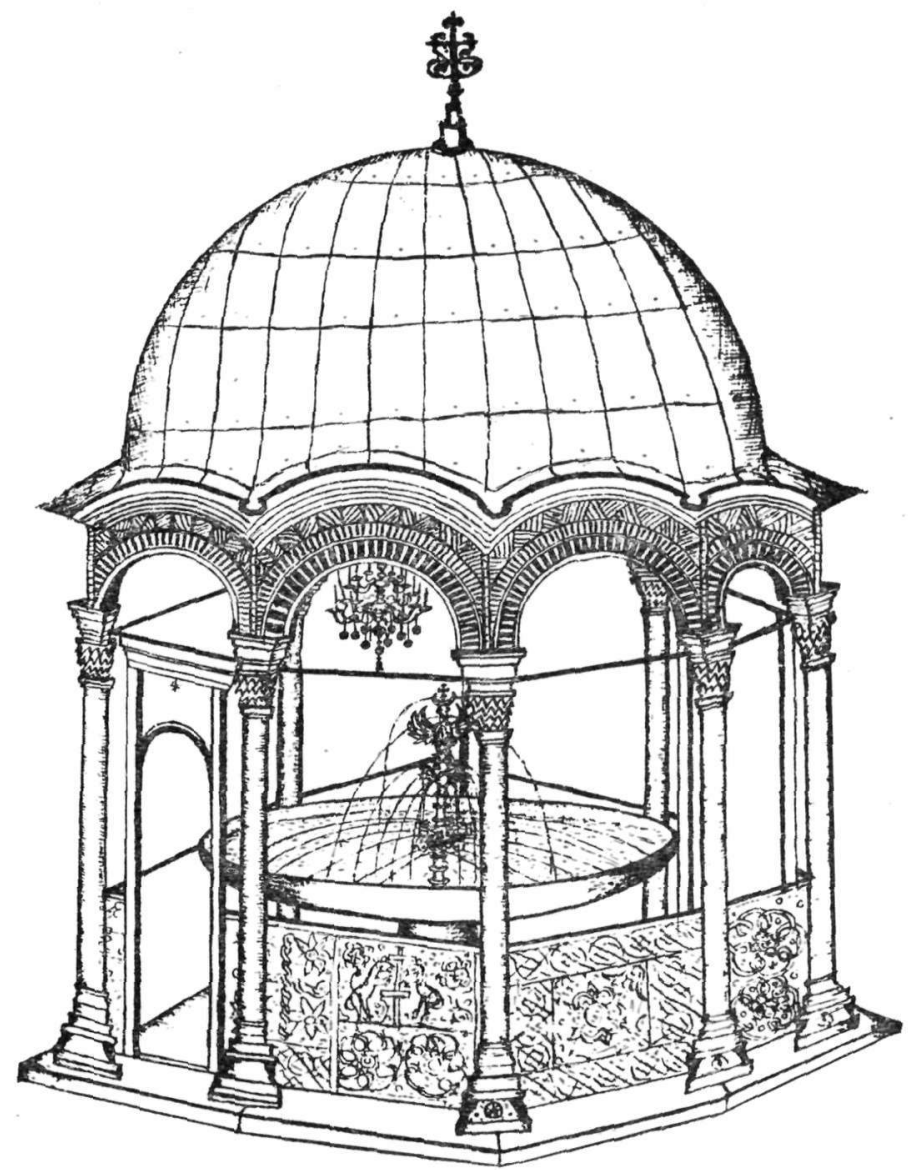

A. Grand Lavra Monastery, phiale. The Barskij drawing.

utes the frescoes to the painters Mercourios and Atzales and dates them to $1635^{16}$. Six of the sides of the octagonal structure are enclosed by deco-

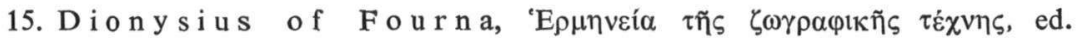
Papadopoullos - Kerameus, Petroupolis 1909, 221.

16. G. Millet, J. Pargoire, L. Pet it, Recueil des inscriptions, op. cit., 129. 
rated marble slabs, mostly double faced, which have been reused ${ }^{17}$ (pls. 47, 48). Stalactite capitals, typical of Ottoman architecture of the sixteenth century (pl. 49) ${ }^{18}$, adorn the eight columns bearing the domed structure. A foliate cross surmounts the dome which is covered by leaves of lead ${ }^{19}$. The massive marble basin is extremely shallow and bears tetrafoil crosses incised on the surface of the rim ${ }^{20}$. From the center of the concave bowl rises the bronze tube, decorated with various zodia in three tiers (pls. 44, $50,51)$.

THE STROBILION. An eagle, its wings outstretched, is represented standing on the top of the bronze tube (pl. 50). Immediately under the bird's legs there is an irregular joint, the trace of some restoration, which is not covered by the usual ringlet placed over the rest of the original joints. In the middle tier there were four dragons, alternating with two winged lionesses and two griffins, fashioned around what might be called a pine-cone. Under each lioness or griffin there was an undulating projection in the form of a foliate scroll whose top resembles the head of a dragon. The lower tier of the trough consisted of four dragons devouring either bulls or rams, which alternated with four single dragons around an enlarged globular ring.

It is obvious that all the zodia were used as water spouts, distributing the water all around the bronze tube through tiny holes on the heads of the animals. It should be noted, however, that the strobilion has suffered considerable losses so far and one dragon, one griffin and one scroll are missing from the middle tier of the trough, while the lower tier has lost one of the two dragons devouring a bull. Most of these losses must have been inflicted during the last thirty years, since they are not visible in an excellent picture of D. T. Rice published in $1949^{21}$. This picture, as well as the detailed drawing of Barskij, prove that the split palmette which rises from a tiny

17. The style of one of these slabs has been related to that of the 9th century sculptural decoration of Scripou, see A. G r a bar, Sculptures byzantines de Constantinople, Paris 1963, 97. Three more of these slabs are discussed in detail in the appendix of the end of this paper.

18. Cf. G. Goodw in, A History of the Ottoman Architecture, London 1971, figs. $255,263,321$.

19. Byzantine church founders provided for the conservation of such lead roofings,

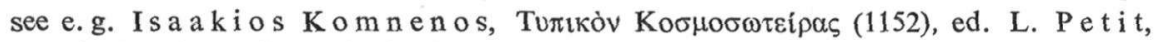
Isvestia Russkago Archeologiceskago Instituta y Konstantinopoli XIII (1908), 59/34.

20. Similar crosses were incised on the rim of various baptisteries, cf. R. D a wk in s, Cruciform Fonts in the Aegean Area, BSA XIX (1912-13), fig. 6b .

21. R. B y r o n, The Station. Athos Treasures and Men, London 1949, op. p. 64. I am grateful to mr. E. Hawkins for drawing my attention on this publication. 
cantharus on top of the eagle's head replaced an earlier cross ${ }^{22}$. Minor damages can also be observed on some of the animals ${ }^{23}$, while their texture is disfigured by successive layers of salt and paint.

ANALYSIS. The eagle was recognized as a symbol of Roman imperial victory and might, as well as a symbol of apotheosis after death ${ }^{24}$. However, eagles were represented on the top of the so-called Orpheus sculptural compositions of late antiquity, which served as fountain elements ${ }^{25}$. Eagles crowning the strobilion of a fountain, on the other hand are well known not only from relevant descriptions in the Byzantine sources ${ }^{26}$, but also from phialae representations in illuminated manuscripts, such as the one in a canontable of the eleventh century Four Gospels of Parma (Cod. Pal. Gr. 5 , fol. $\left.8^{r}\right)^{27}$, or another in a scene of the Barlaam and Joasaph copy of the Iveron monastery at Mount Athos (Cod. 463, fol. 110 $\left.{ }^{\mathrm{r}}\right)^{28}$. In spite of all that, the upturned feathers and the form of the eagle's outstretched wings on the Lavra conduit are unfamiliar to the Byzantine pictorial tradition, which usually adopts more compact, conventionalized forms. Moreover, the irregular joint underneath the eagle's legs (pl. 50) and the abrupt end of its tail (pl. 51a) support the idea that the eagle represents a later addition.

The winged lion became widely known as a symbol of St. Mark. This fabulous animal, though often depicted in illuminated manuscripts of the eleventh and the twelfth centuries ${ }^{29}$, is only rarely found in Byzantine sculptures. Winged lionesses, however, support the base of the two monu-

22. Cf. G. M i 11 e t, Recherches au Mont-Athos, op. cit. 107.

23. Thus the legs of the only surviving griff in were broken after 1964, cf. pls. 50 and $51 \mathrm{a}$.

24. J. T o y n be e, Animals in Roman Life and Art, London 1973, 2.42.

25. Ibid., 290 ff.; cf. A. G r a b a r, Le premier art chrétien, Paris 1966 fig. 101.

26. See e.g. Theophanes Continuatus, op. cit., $451 / 7, \ldots \dot{a} \varepsilon \tau \dot{o} v \dot{e ́ \xi}$

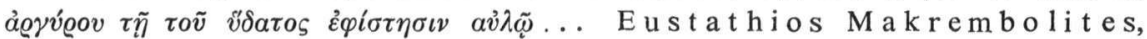

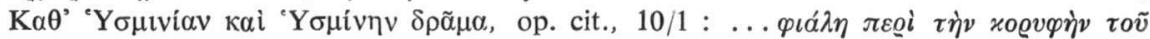

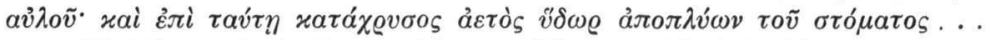

27. Photo of the Benaki Museum Photographical Archive.

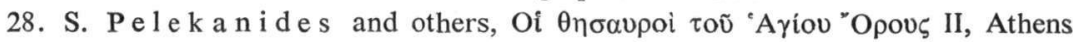
1975, 79 fig. 106.

29. Cf. e. g. J. Strzy g o w ski, Der Bilderkreis des griechischen Physiologus,

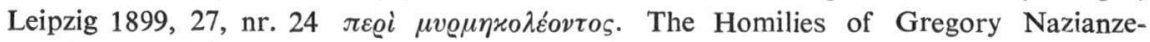
nus in Paris (Bibl. Nat. Cod. Gr. 550, fol. 166v), in G. G a 1 a v a r i s, The Illustrations of the Liturgical Homilies of Gregory Nazianzenus, Princeton 1969, fig. 423. 
mental candelabra of San Giorgio in Venice ${ }^{30}$. The fact that lion heads continued to be used as water spouts by Byzantine craftsmen whether in springs and fountains ${ }^{31}$, or in church architecture ${ }^{32}$, might be related to the lionesses decorating the Lavra strobilion. It is also interesting to note that several Islamic bronzes in the form of lions, dated to the eleventh and the twelfth centuries, are either regarded as fountain elements or as aquamaniles ${ }^{33}$.

The griffins, on the other hand, alternating with the winged lionesses in the middle tier of the Lavra strobilion, enjoyed a most impressive popularity in all the Byzantine arts. Combining the body of a lion and the head of an eagle, these imaginary animals were adopted by the Greeks and the Romans ${ }^{34}$. Later on, the griffins represent one of the outstanding elements in the decoration of the two-zone capitals ${ }^{35}$. Moreover, heraldic griffins flanking the Fountain of Life are often found, as for instance on one of the panels of the bronze doors of Salerno ${ }^{36}$; the same theme appears in several marble slabs, such as the one decorating the north-eastern side of the octagonal structure covering the Lavra fountain ${ }^{37}$. Two more examples of this kind may be observed on the facade of the church of Gorgoepekoos in Athens ${ }^{38}$.

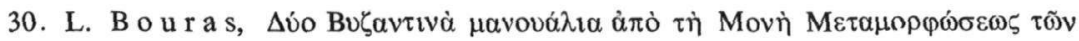

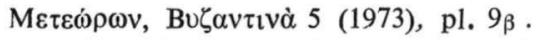

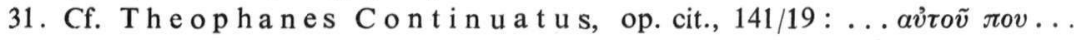

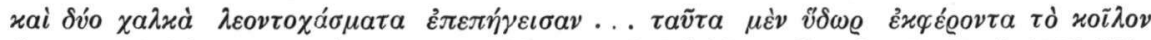

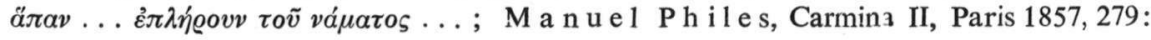

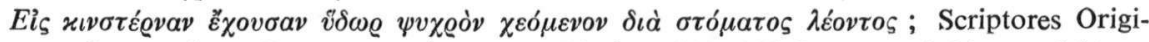

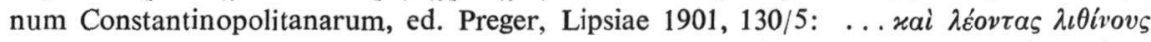

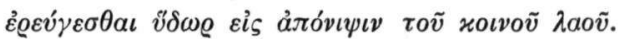

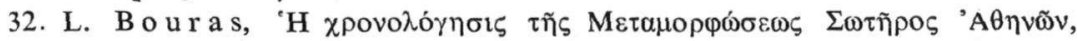

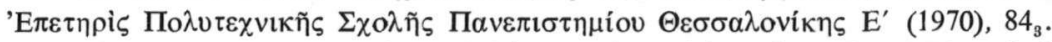

33. E. Cruikshank-Dodd, On the Origins of Medieval Dinanderie, A.B. LI (1969), figs. 1, 3, 7, 8 .

34. Paulys Real-Encyclopädie der Classischen Altertumswissenschaft 7, Stuttgart 1912, col. 1924. For a Byzantine description of the fabulous animal see Photi us the

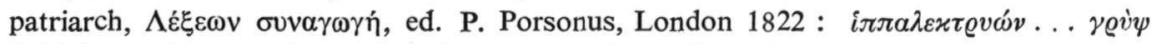

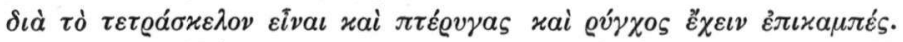

35. E. Kitzinger, The Horse and Lion Tapestry, DOP 3 (1946), 49 ff. ;

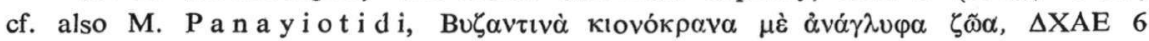
(1970 - 72), $90 \mathrm{ff}$.

36. M. Frazer, Church Doors and the Gates of Paradise : Byzantine Bronze Doors in Italy, DOP 27 (1973), fig. 22.

37. A. G r a b a r, Sculptures byzantines de Constantinople, op. cit., pl. $\mathbf{X L V}_{\mathbf{B}}$.

38. Ibid,, pl. LXIV ${ }_{2}$. Some more carved slabs of this kind see in F. $\mathrm{Zu}$ li a ni, I marmi di San Marco, Venezia 1972, fig. 143; H. B uchwald, The Carved Stone Ornament of the High Middle Ages in San Marco, Venice, JÖBG 11-12 (1962 - 63), fig. 2. 
Griffins were also used as water spouts on the Athenian dome of St. Nicolas at Ochia, Mani, which has been dated to the middle of the twelfth century ${ }^{39}$. Finally it has been suggested that the Fatimid monumental bronze griffin of the Campo Santo in Pisa originally served as a fountain element ${ }^{\mathbf{4 0}}$.

Dragons, nevertheless, whether devouring other animals, or single, seem to outnumber all other zodia in the decoration of the Lavra conduit. This particular feature, i.e. dragons acting as water spouts of a fountain, is often depicted in eleventh and twelfth century Constantinopolitan manuscripts, as in the copy of the Homilies of Gregory Nazianzenus in Paris (Bibl. Nat. Cod. Gr. 550, fols. $59^{\mathrm{r}}$ and $\left.166^{\mathrm{r}}\right)^{41}$ and in the Homilies of the Virgin by the monk James of Kokkinobaphos (Cod. Vat. Gr. 1162, fol. $\left.16^{\mathrm{r}}\right)^{42}$. The same feature appears in monumental Palaeologan painting, namely in a fresco depicting Gregory Nazianzenus as a Source of Wisdom, at Mistra ${ }^{43}$. Such representations may well have been inspired by the transformation of the Serpent Column in the Hippodrome of Constantinople into a fountain, which was ascertained by the British excavations of $1927^{44}$.

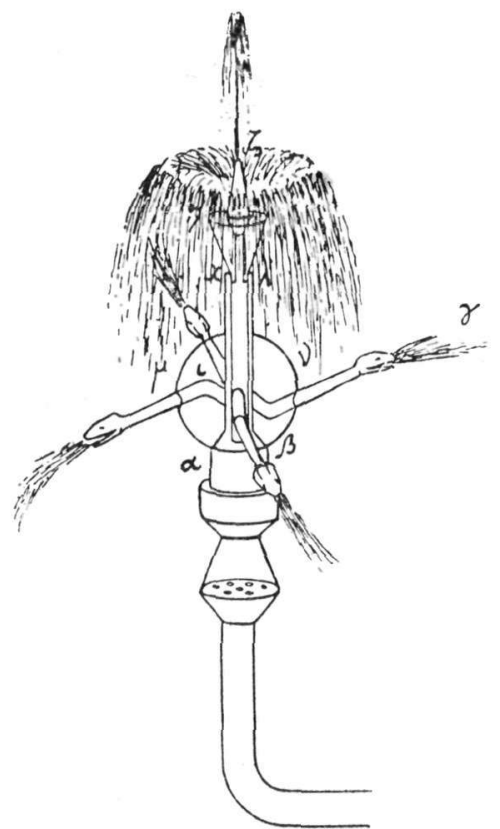

B. Strobilion attributed to Philon of Byzantium (after Carra de Vaux). Furthermore, four serpents served as water spouts around the classical strobilion (B) attributed to the Hellenistic engineer Philon of Byzantium (ca.

39. On the dating of the monument see H. M e gaw, Byzantine Architecture in Mani, BSA 33 (1932 - 33), 162.

40. G. M i g e o n, Manuel d'art musulman, Arts plastiques et industriels I, Paris $1927,374$.

41. G. G a l a varis, The Illustrations of the Liturgical Homilies of Gregory Nazianzenus, Princeton 1969, figs. 412, 423.

42. C. S tornajo lo, Miniature delle Omilie di Giacomo Monaco e dell' Evangeliario Greco Urbinate, Roma 1910, pl. 6.

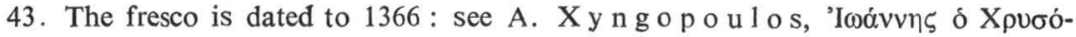

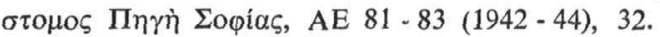

44. Preliminary Report upon the Excavations carried out in the Hippodrom of Constantinople in 1927, London 1928, 14. 
250 B.C.), as preserved in an Islamic illuminated manuscript in the Boldeian Library ${ }^{45}$. The fact that the ancient Greek legendery association between dragon and water survived in Byzantium ${ }^{46}$ on the other hand, offers an additional plausible explanation for the particular application of the fabulous monster.

Ram heads, though less popular than lion heads, were also used as water spouts in ancient Greece and it has been attested that they survived in theodosian architecture ${ }^{4}$. Bronze cocks, rams and goats, on the other hand, spread jets of water around the second phiale of the Nea, according to the description in the Vita Basilii ${ }^{48}$. The pronounced plasticity, the vitality and the general stance of the bulls and the rams, as if rushing to escape the dragons, in the lower tier of the Lavra strobilion, however, may be compared to the bull and the ram protomes decorating some two-zone capitals, like those found in the basilica $\mathrm{C}$ of Amphipolis ${ }^{49}$.

Quite apart from the individual significance attributed to the various zodia depicted, wild and fabulous animals were, nevertheless, used to frame the so-called Orpheus sculptural compositions of late antiquity, which served as fountain elements ${ }^{50}$. The significance of these representations pointed to the heavenly peace in which all kinds of animals are tamed by the harmony and order that music implies ${ }^{51}$. The symbolical meaning of the phiale as part of the paradisiac iconography ${ }^{52}$ may well offer a parallel explanation to that of the Orpheus compositions, wherein all kinds of wild and

45. Philon of Byzantium, Le livre des appareils pneumatiques et des machines hydrauliques, ed. Le baron Carra de Vaux, Paris 1902, 204 - 205.

46. Several descriptions in the synaxaries of dragon slaying saints refer to the dragon as inhabiting some source of water, whether river, source, or well, revealing the traditional relation of dragon to water, see Reallexikon für Antike und Christentum IV, Stuttgart 1959, 245.

47. Cf. W. B. D i n s m o or, The Architecture of Ancient Greece, London-New York 1950, 90, 113. M. G o u g h, Alahan Monastery. Fourth Preliminary Report, Anatolian Studies XVII (1967), pl. Va,b.

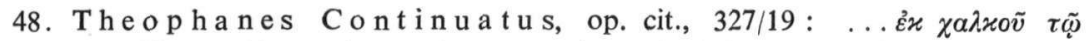

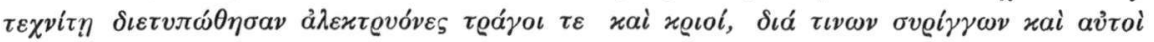

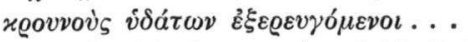

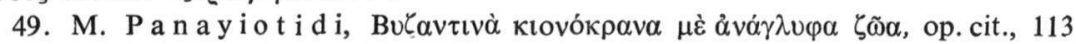
nrs. 231, 232.

50. J. T o y n b e e, Animals in Roman Life and Art, op. cit., $290 \mathrm{ff}$.

51. Ibid. 289. The decoration of certain early Christian slabs probably related to the rite of baptism with similar subjects, may refer to the same symbolical context, cf. E. Kitzinger, A Marble Relief of the Theodosian Period, DOP 14 (1960), 32.

52. M. Frazer, Byzantine Bronze Doors in Italy, op. cit., 161. 
fabulous animals are tamed by the harmony and order reigning in His Eternal Kingdom ${ }^{53}$.

CONCLUSIONS. In spite of the poor state of preservation of the strobilion of the Lavra phiale, the graceful and homogeneous modelling of the zodia in the two lower tiers reveals a high quality craftsmanship. It may also be added that the plasticity of some of the zodia, such as the bulls and the rams, resembles that of good early Christian models. The articulation of the conduit as a whole recalls tenth and twelfth century descriptions of similar works in the Byzantine sources and certain representations of the Fountain of Life in illuminated manuscripts and monumental painting. It is therefore very likely that the Lavra trough represents a unique Byzantine work cast in bronze ${ }^{54}$, still standing in its original position, most probably dated to about the middle of the eleventh century. The graceful modelling of the $z o$ dia favors such an early dating, which coincides with the great flourishing of metalwork in the Constantinopolitan workshops mentioned some years earlier by Psellos himself in his Chronographia ${ }^{55}$ and proved by the exportation of Byzantine bronze doors to Italy ${ }^{56}$.

It is true, nevertheless, that the eagle seems out of proportion with the rest of the zodia. Moreover, the shape of its outstretched wings, not only differs from those of the lionesses and the griffins underneath, but seems altogether unfamiliar to the Byzantine traditional forms. Thus its stylistic differentiation, as well as, the abrupt end of its tail and the irregular joint right under its legs, suggest that the eagle, though often used by the Byzantine craftsmen as a fountain head, should in fact be considered a latter addition, related to some drastic restoration of the conduit. The fact

53. Eus e bi us refers to the parallel between the effects of Christ's words upon human beings and those of Orpheus's music upon beasts, see Eusebius Werke I, op. cit., $242 / 15$. On the origin of the animal imagery implying paradisiac context see A. G r a b a r, Recherches sur les sources juives de l'art paléochrétien. L'art de la fin de l'antiquité et du moyen âge II, Paris 1968, 760.

54. Macarios of Egypt (301 - 391 A.D.) refers to a method of casting bronze zodia

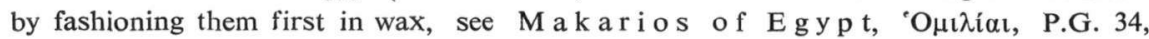

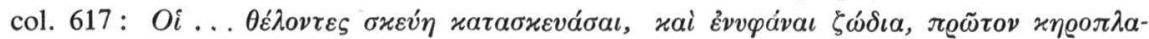

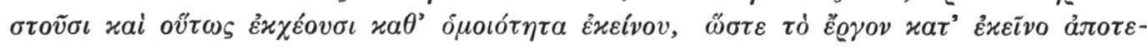
$\lambda \varepsilon \sigma \theta \tilde{\eta} v \alpha \iota$ cò $\sigma \chi \tilde{\eta} \mu \alpha$.

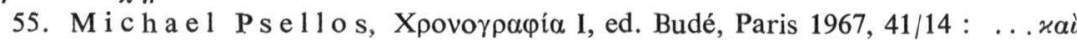

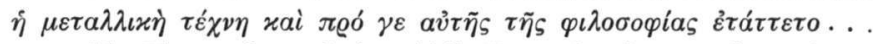

56. The earliest of the middle Byzantine bronze doors in Italy is that of Amalfi, presumably dated ca. 1060, see M. Frazer, Byzantine Bronze Doors in Italy, op. cit., 147. 
that the eagle is clearly discernible in Barskij's drawing (A), proves that this restoration occured before Barskij visited the monastery in $1744{ }^{57}$. It is highly possible that this activity might be related to the erection or rather to the drastic restoration of the octagonal canopy ${ }^{58}$ which was completed most probably a few years before it was decorated with frescoes in $1635^{59}$. Since we do know that the phiale was concecrated in $1060^{60}$, it would be reasonable to assume that the restoration of the bronze conduit and the new octagonal structure were both connected with the destructive earthquake of 1585, which distorted the domes of the church and the hospital, and caused the refectory to be dismantled ${ }^{61}$.

The Lavra strobilion, no doubt based on the mechanics of Philon of Byzantium and Heron of Alexandria ${ }^{62}$, is particularly important, because it represents the only surviving specimen which proves that the relevant descriptions in the Byzantine sources may well refer to actual and not to imaginary water spout conduits. It also proves that manuscript illuminators and painters may have used actual models, at least occasionally. Finally it shows that the Hellenistic technical knowledge continued to serve and amuse the Byzantine people. If properly cleaned, the Lavra strobilion, most probably dated to ca. 1060 and possibly ordered in some Constantinopolitan workshop by the influential John, epi tou koitonos and epi tou Kanikleiou, appointed ephore of the Grand Lavra monastery by a chrysobull of Constantine Monomachos in $1052^{63}$, may yield additional information on the casting techniques, the plastic arts and the hydraulics of Byzantium in the eleventh century.

57. Cf. G. Mille t, Recherches au Mont-Athos, op. cit., 107.

58. If we do accept that the bronze strobilion represents an element of the original phiale, it is most unlikely that such a complicated and expensive water-spouting conduit was left uncovered in the open air.

59. See note 16 supra.

60. See note 11 supra.

61. A vivid description of this earthquake survived in the form of a note added to one of the Lavra manuscripts; see G. Millet, J. Pargoire, L. Pet it, Recueil des inscriptions, op. cit., 128.

62. It is well known that all the Byzantine mechanical toys such as the strobilia and the automata were based on the devices of these two engineers, see L. Sprague d e C a m p, The Ancient Engineers, London 1963, 269; G. B r et t, The Automata In the Byzantine (Throne of Solomon), Speculum XXIX (1954), $477 \mathrm{ff}$.

63. P. Lemerle, A. Guillou, N. Svoronos, Actes de Lavra I, Paris 1970, 191. 


\section{A P P E N D I X}

THE SLABS. Three of the marble slabs framing the Lavra phiale, namely those forming the south west (one) and the south(two) closures of the octagon seem to belong to the same group (pls. $47 \mathrm{a}, 48_{\mathrm{a}}$ ) and may in fact be attributed to the eleventh century decoration of the phiale. Their exterior side is decorated with a foliate cross ${ }^{1}$ placed under a slender arch, supported by tiny spiral or zig-zag columns. This central motif is framed by foliated scrolls, which in two of the slabs are inhabited by tiny zodia picking up the overhanging grapes ${ }^{2}$. The ground of this champleve frame was obviously covered with some coloured inlay in the fashion of the so-called niello technique ${ }^{3}$. The remains of another foliate scroll extending west of the frame of the south-western closure suggest that each slab originally included not one, but two foliate crosses, each one surrounded by its own inlay frame. Thus the total width of the slab corresponded to the openings of the octagonal canopy.

The other side of the three slabs (pls. $47 \mathrm{~b}, 48 \mathrm{~b}$ ), is divided by knotted tripartite bands into four panels containing depictions of various animals, or eight pointed stars ${ }^{4}$. It is interesting to note that these animals include heraldic peacocks flanking the Fountain of Life, eagles devouring serpents ${ }^{5}$,

1. On the significance of the foliate cross see M. F r a zer, Byzantine Bronze Doors in Italy, op. cit., 148.

2. These bands, whose foliated scrolls reveal Islamic influences, resemble both in style and technique a marble fragment in the Byzantine Museum in Athens, see G. S o te r i o u, Guide du Musée Byzantin d'Athènes, Athènes 1932, nr. 321, fig. 39 $\beta$; on the origin of the peopled scrolls see J. T o yn bee, J. W a rd Perkins, Peopled Scrolls, A Hellenistic Motif in Imperial Art, P.B.S.R. XVIII (1950), 1.

3. H. Buchwa Id, The Carved Stone Ornament of the High Middle Ages in San Marco, Venice, op. cit., $172 \mathrm{ff}$. The same technique was widely applied in the architectural decoration of the church of the Virgin in St. Luke's monastery, see A. G r a b a r, La décoration architecturale de l'église de la Vierge à Saint - Luc en Phocide, C.R.A.I. 1971, $21 \mathrm{ff}$.

4. Stars originally signifying Paradise were also used for the decoration of Byzantine bronze doors; see $\mathrm{Ch}$. B o u ras, The Byzantine Bronze Doors of the Great Lavra Monastery on Mount Athos, JÖB 24 (1974), 239.

5. On that theme see R. Wittcower, Eagle and Serpent, J.W.C.I. 2 (1938 - 39) passim. 
harts, harpies and griffins, in all cases closely related to the paradisiac symbolism of the phiale ${ }^{6}$.

Thus the size and the iconography of the three slabs discussed support the idea that they may belong to the original, eleventh century decoration of the phiale, while the refined inlay technique revealing Islamic influences and the inhabited scrolls suggest a Constantinopolitan origin.

LASKARINA BOURAS

6. See note 52 supra; cf. C. S heppard, Byzantine Carved Marble Slabs, A.B. 51 (1969), 65 ; A. G r a b a r, Sculptures byzantines du moyen âge II, Paris 1976, pl. XLa. 


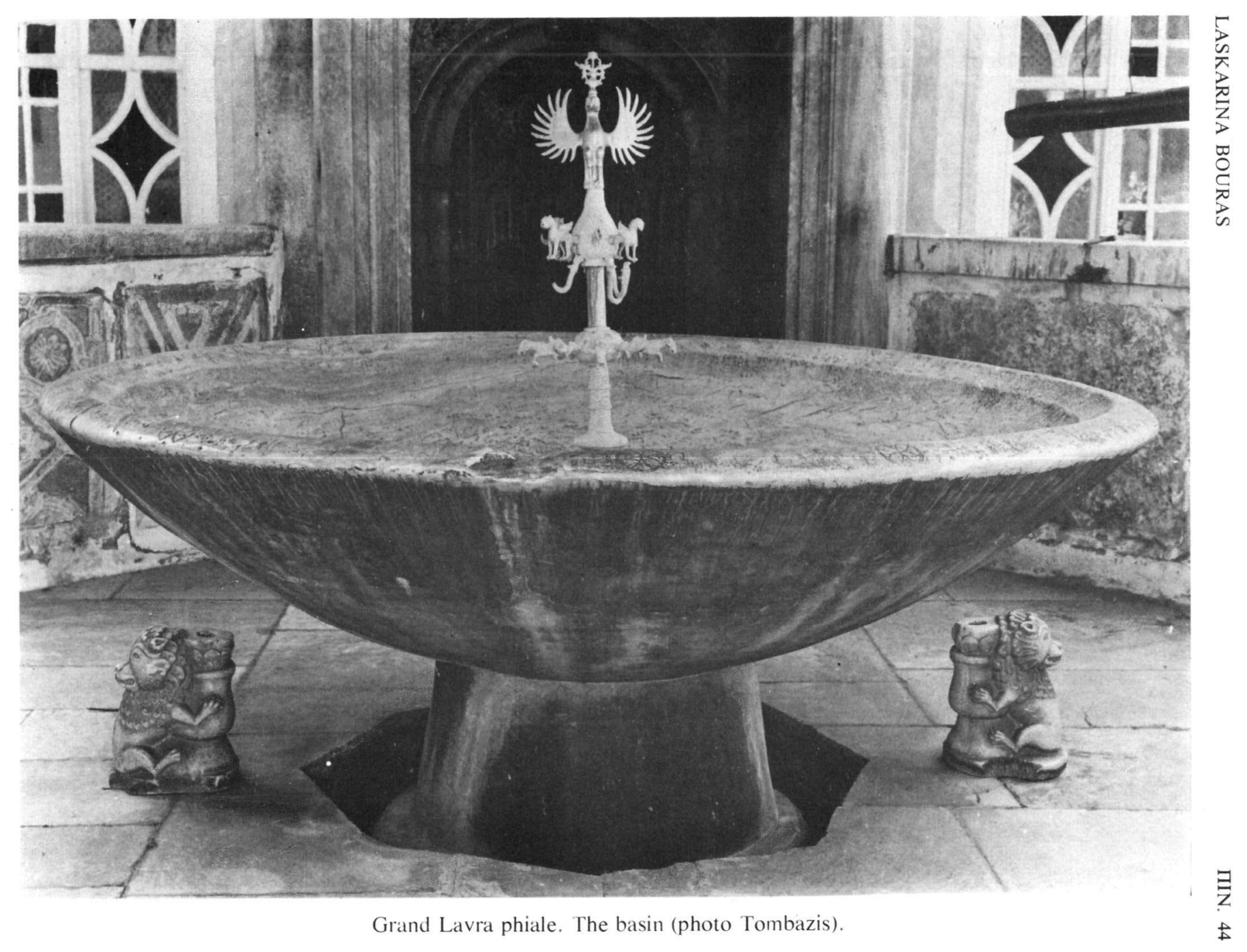




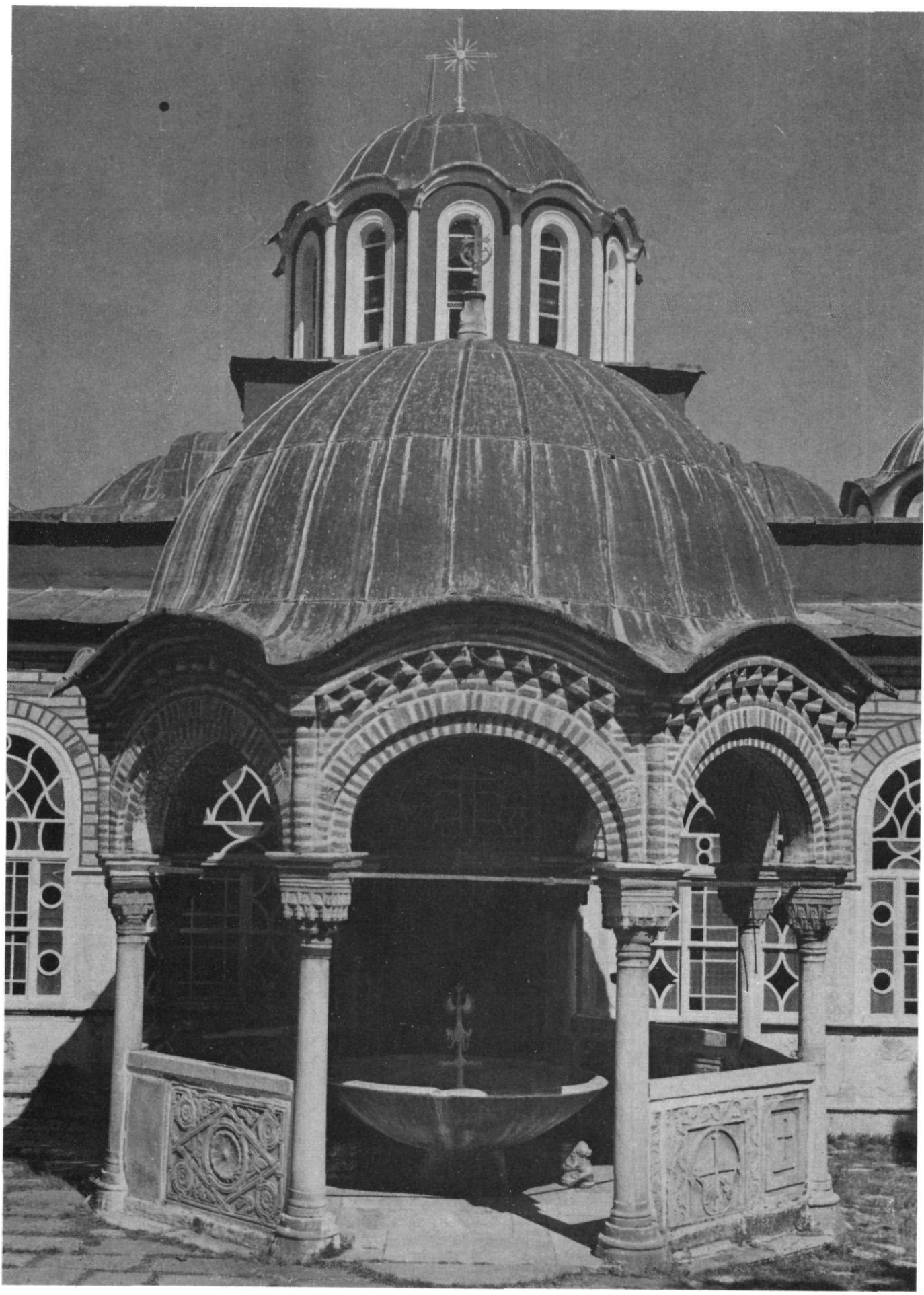

Grand Lavra phiale. The canopy (photo Tombazis). 


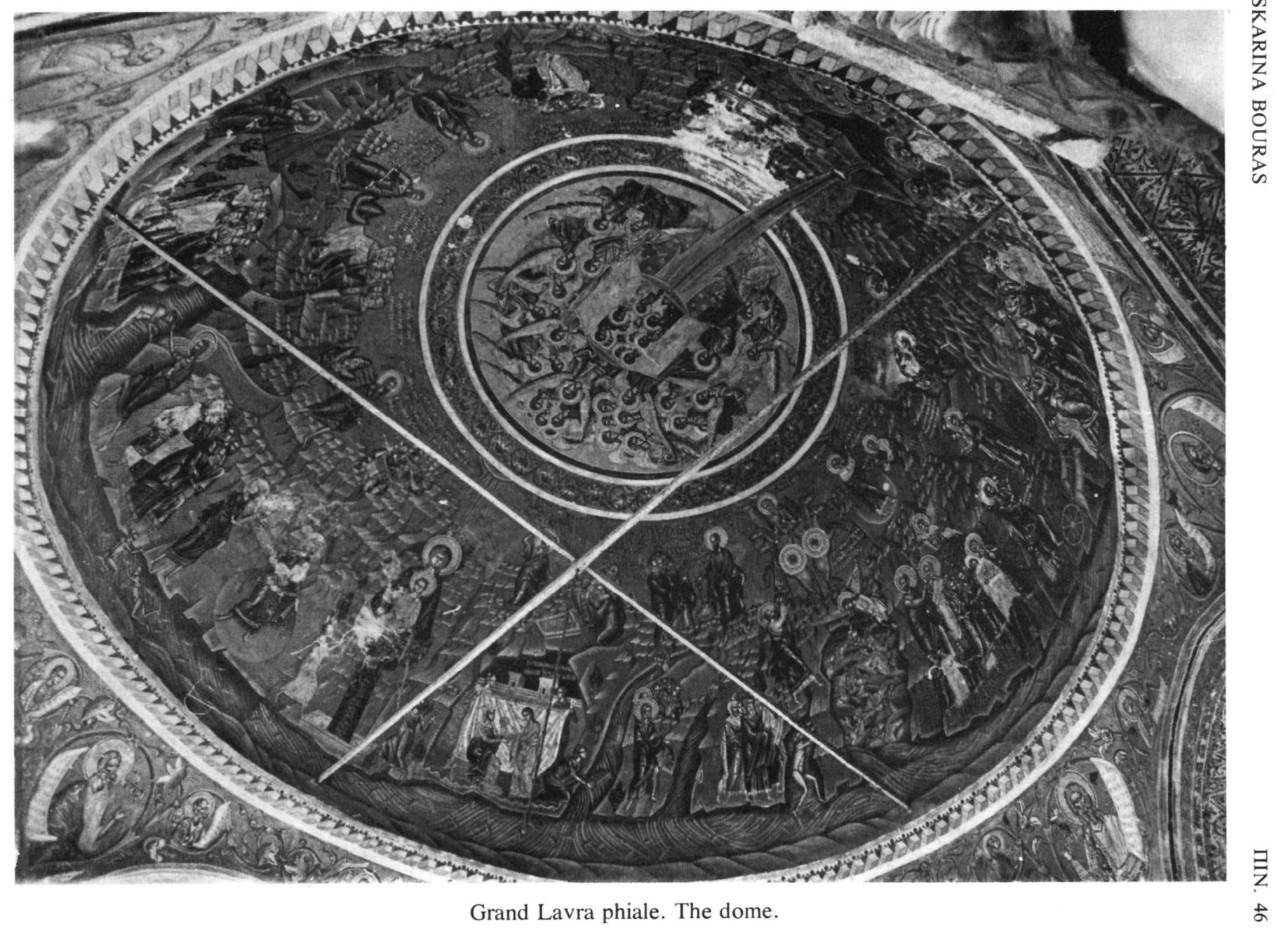



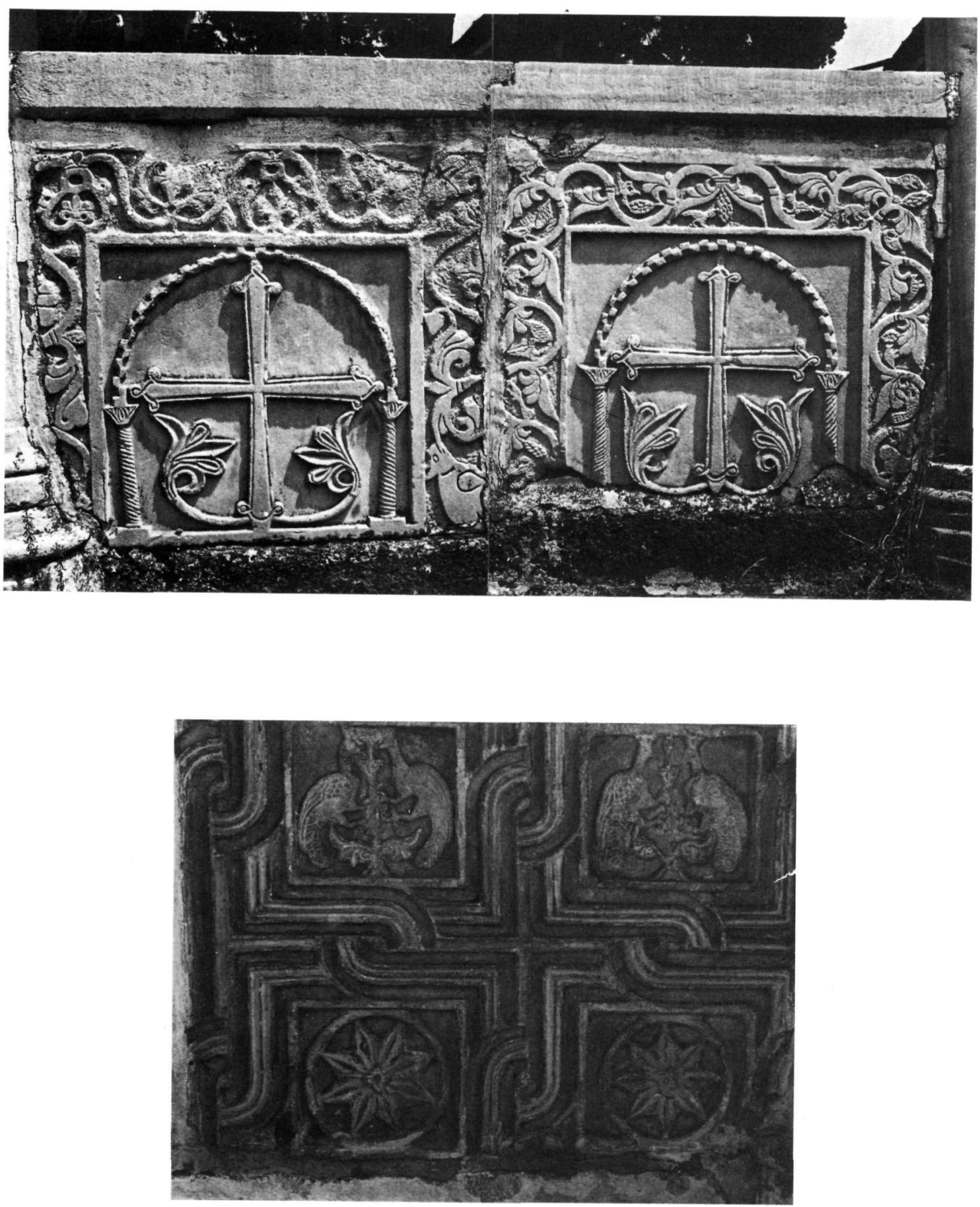

Grand Lavra phiale. a, b. Marble slabs, southern closure (b, photo Velenis). 

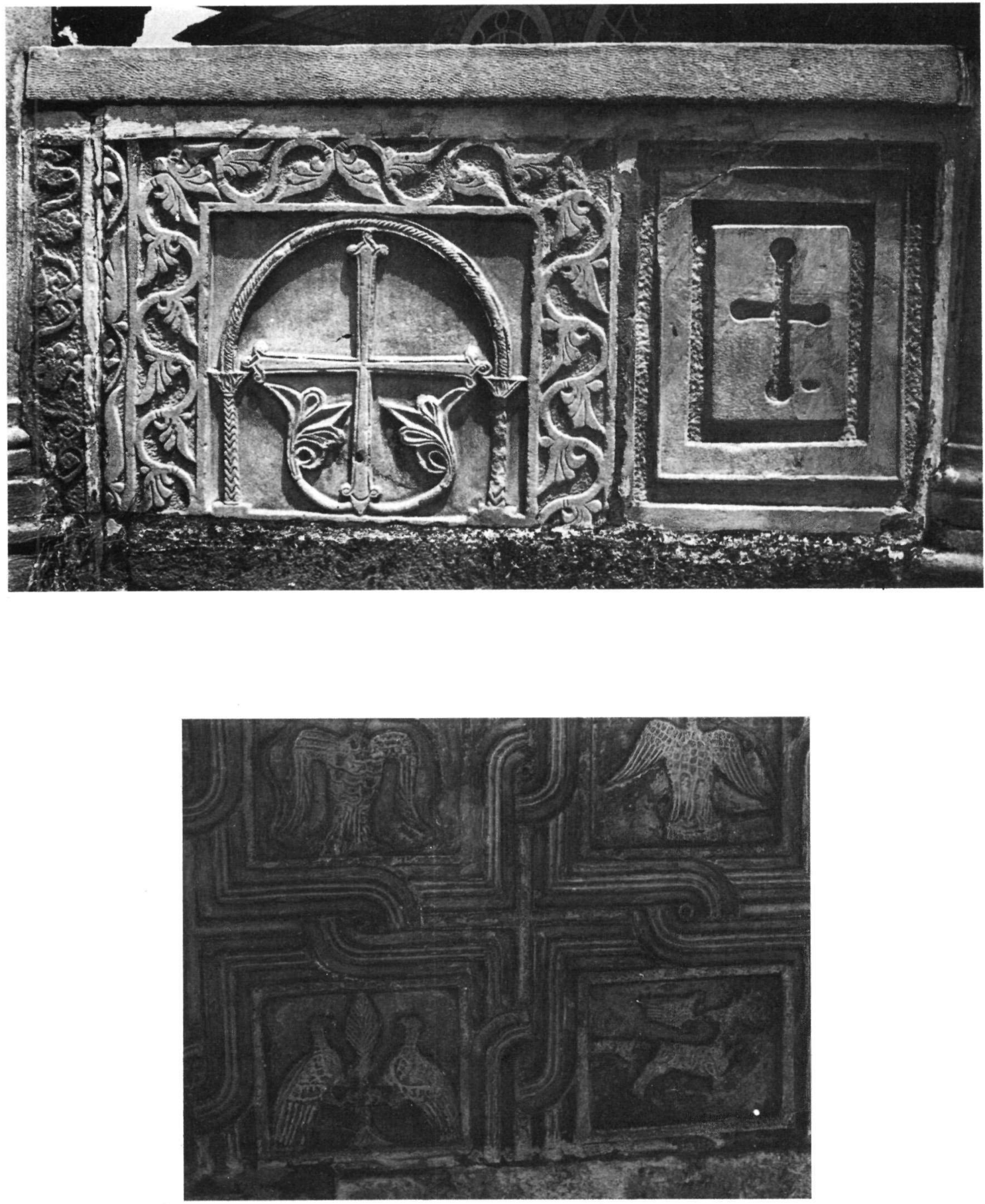

Grand Lavra phiale. a,b. Marble slabs, south western closure (b,photo Velenis). 


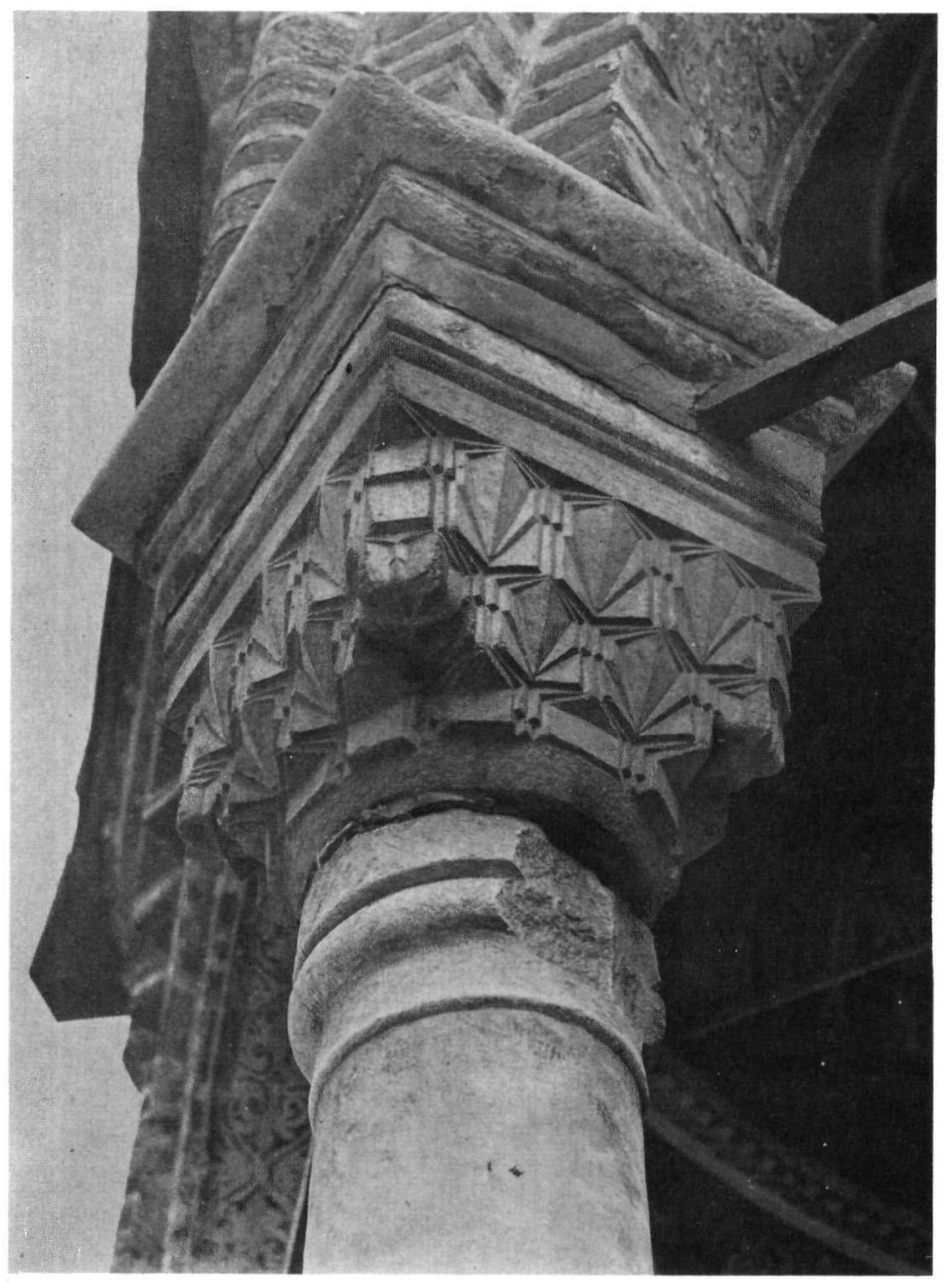

Grand Lavra phiale. A capital. 


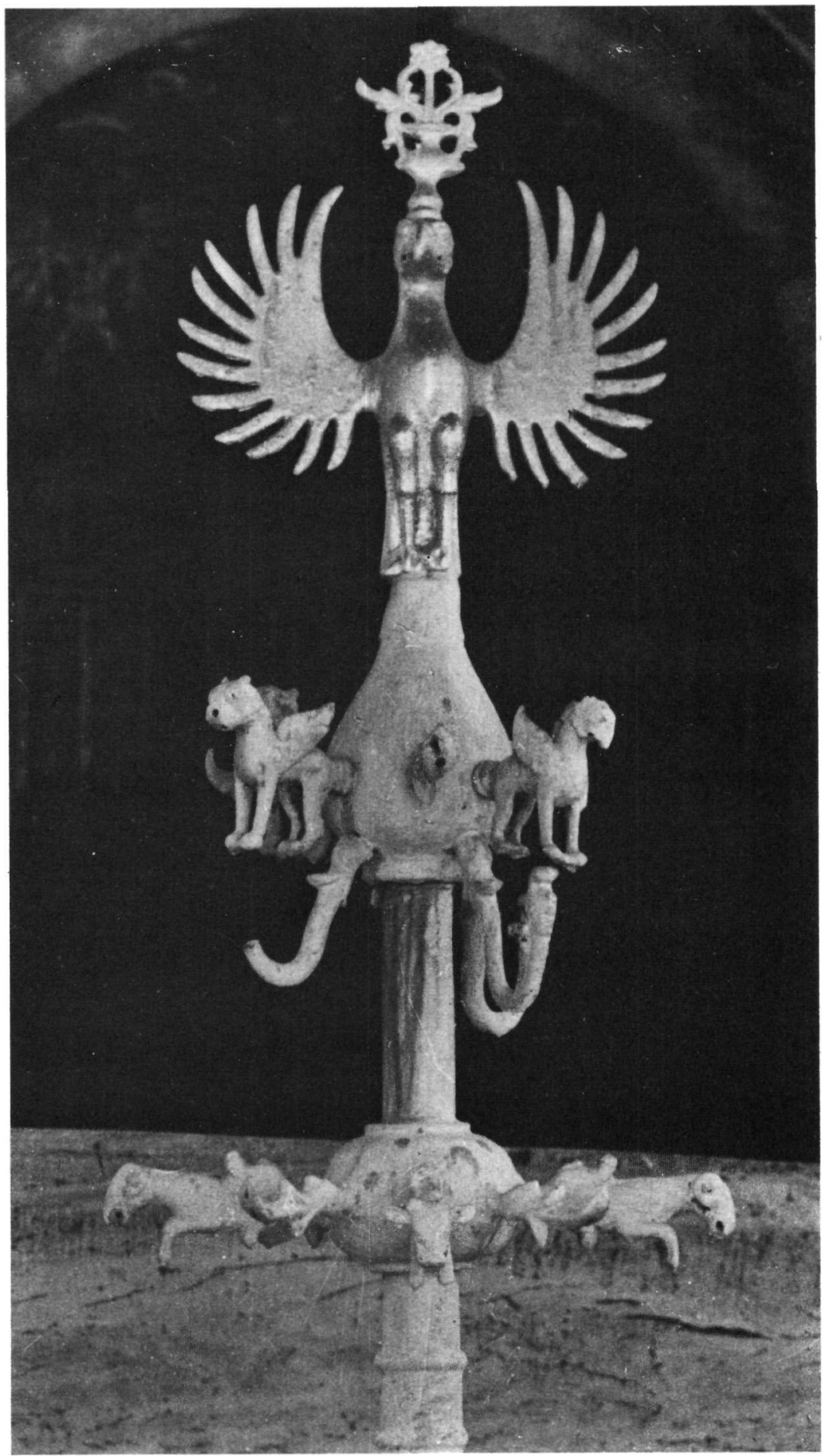

Grand Lavra phiale. The strobilion (photo Tombazis,' 1964). 

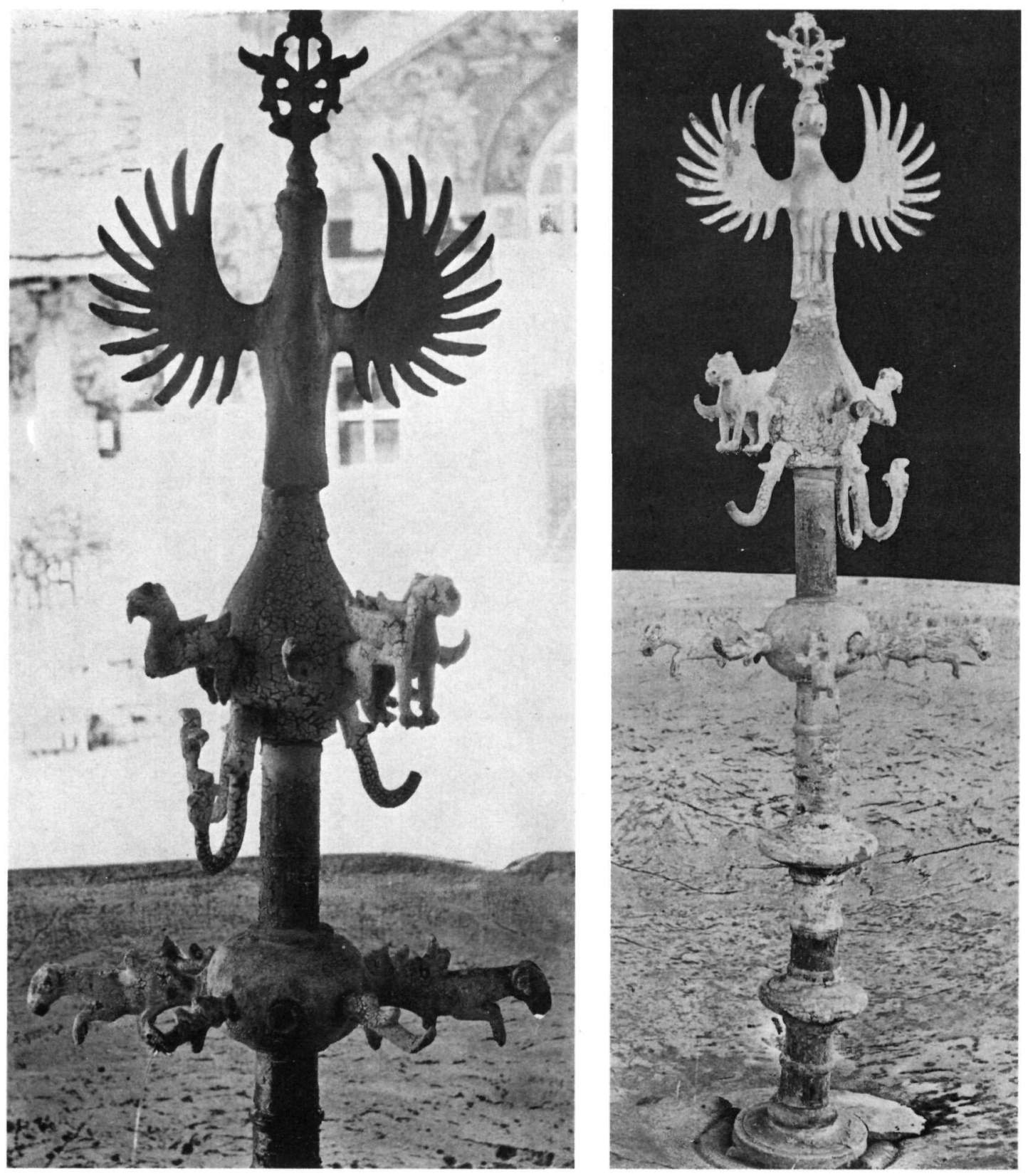

Grand Lavra phiale. a,b. The strobilion (a, photo Vokotopoulos, 1975). 